\title{
ALKYLATION OF PROTEINS BY ARTEMISININ
}

\author{
EFFECTS OF HEME, $\mathrm{pH}$, AND DRUG STRUCTURE \\ Ying-Zi Yang, ${ }^{*}$ Bryan Little and Steven R. Meshnick $\dagger$ \\ Department of Epidemiology, University of Michigan School of Public Health, Ann Arbor, \\ MI 48109, U.S.A.
}

(Received 26 January 1994; accepted 22 March 1994)

\begin{abstract}
Artemisinin and its derivatives are a promising new class of antimalarial agents containing an endoperoxide bridge. $\left[{ }^{14} \mathrm{C}\right]$ Artemisinin alkylated various proteins in vitro. Between 5 and $18 \%$ of added drug bound to hemoproteins such as catalase, cytochrome $c$, and hemoglobin. However, it did not react with heme-free globin. For catalase and hemoglobin, most of the drug reacted with the protein moiety rather than the heme. Artemisinin bound to human serum albumin (HSA) more efficiently at $\mathrm{pH}$ 8.6 than 7.4, more efficiently in Dulbecco's PBS than in Tris-HCl buffer, and better when HSA had been made fatty acid-free. Dihydroartemisinin also bound to HSA, whereas deoxyartemisinin, an inactive derivative, did not. There was no binding between DNA and artemisinin. These data provide insight into the mechanism of the reaction between artemisinin and proteins.
\end{abstract}

Key words: malaria; antimalarial; qinghaosu; endoperoxide

Artemisinin (qinghaosu), a sesquiterpene endoperoxide, was first isolated in 1972 from Artemisia annua, an ancient Chinese herbal remedy for fever [1-3]. Since then, artemisinin and its derivatives, such as dihydroartemisinin, artemether, arteether, and artesunate, have been widely used for the therapy of malaria in China, Vietnam, and Burma [4]. Over three million doses of artemether have been administered in China alone [4]. Artemisinin derivatives are particularly useful against chloroquine-resistant Plasmodium falciparum strains and cerehral malaria and are currently undergoing phase I and phase II clinical studies $[4,5]$.

Artemisinin appears to be activated by intraparasitic iron into a free radical, which then acts as an alkylating agent. Evidence for the role of free radicals includes observations that free radical scavengers antagonize the antimalarial activity of artemisinin $[6-8]$, the necessity of the endoperoxide bridge for antimalarial activity $[2,3]$, as well as the observation of an iron-generated free radical by electron paramagnetic resonance spectroscopy [9]. The catalysis has been demonstrated by cyclic voltammetry [10], and the decomposition products have been identified [11]. The alkylation of proteins by artemisinin has also been demonstrated using HSA $\ddagger[12]$ and red cell membrane proteins [13] as models. The covalent nature of the bond was confirmed by electrospray mass spectrometry [12]. Heme is also alkylated $[14,15]$. In this paper, the

* Current address: Division of Endocrinology, Department of Internal Medicine, University of Michigan Medical School, Ann Arbor, MI 48109-0678.

† Corresponding author: Dr. Steven Meshnick, Department of Epidemiology, University of Michigan School of Public Health, 109 Observatory St., Ann Arbor, MI 481092029. Tel. (313) 747-2406; FAX (313) 764-3192.

$\ddagger$ Abbreviation: HSA, human serum albumin. mechanism of the reaction between artemisinin and proteins has been further characterized.

\section{MATERIALS AND METHODS}

$\left[{ }^{14} \mathrm{C}\right]$ Artemisinin $(45.4 \mathrm{Ci} / \mathrm{mol})$ and deoxyartemisinin were gifts from the Division of Experimental Therapeutics, Walter Reed Army Institute of Research, Washington, DC. Dihydroartemisinin was a gift from Dr. H. Z. Pan, Institute of Basic Medical Sciences, Beijing, China. Dulbecco's PBS was from Gibco BRL (Grand Island, NY). Blood (Type $\mathrm{A}^{+}$) was purchased from the Interstate Blood Bank, Memphis, TN. Red blood cell lysate was prepared by mixing fresh blood cells with hypotonic buffer $\left(10 \mathrm{mM} \mathrm{NaH} \mathrm{PO}_{4}, 6.6 \mathrm{mM}\right.$ $\mathrm{Na}_{2} \mathrm{HPO}_{4}, \mathrm{pH}$ 7.4) [16] and then removing membranes by centrifuging at $11,525 \mathrm{~g}$ on a microcentrifuge. Bradford protein reagent was purchased from Bio-Rad Laboratories (Richmond, CA). Artemisinin, bovine liver catalase, horse heart cytochrome $c$, HSA (globin-free), HSA (fatty acidfree, globin-free), methemoglobin, salmon testes DNA, and all other chemicals were purchased from the Sigma Chemical Co. (St. Louis, MO).

Reactions between artemisinin and proteins. Reaction mixtures contained $1 \mathrm{mg} / \mathrm{mL}$ of the appropriate protein and $11 \mathrm{nCi} / \mathrm{mL}\left[{ }^{14} \mathrm{C}\right]$ artemisinin in PBS ( $\mathrm{pH} 7.4)$. Control reaction mixtures lacking protein were carried out in tandem under identical conditions. After $24 \mathrm{hr}$ incubations at $37^{\circ}$, a $500 \mu \mathrm{L}$ aliquot from each mixture was applied to an NAP5 size-exclusion column (Pharmacia, Uppsala, Sweden) preequilibrated in PBS, pH 7.4. The protein content of the eluate was determined by the method of Bradford [17]. High and low molecular weight material separated with the initial $0.9 \mathrm{~mL}$ eluate and the subsequent $3 \mathrm{~mL}$ eluate, respectively. A $100 \mu \mathrm{L}$ 
Table 1. Binding of $\left[{ }^{14} \mathrm{C}\right]$ artemisinin to various proteins and to DNA

\begin{tabular}{lcc}
\hline \multicolumn{1}{c}{ Target } & pmol bound/mg protein & Percent radioactivity bound \\
\hline Albumin (fat-free, globin-free) & $41.8 \pm 1.3$ & $10.9 \pm 0.4$ \\
Albumin (globin-free) & $8.5 \pm 0.9$ & $2.4 \pm 0.3$ \\
Catalase & $23.9 \pm 1.6$ & $8.3 \pm 0.4$ \\
Cytochrome $c$ & $14.3 \pm 0.9$ & $4.8 \pm 0.4$ \\
Globin & $3.7 \pm 0.8$ & $1.6 \pm 0.3$ \\
Methemoglobin & $43.7 \pm 8.2$ & $18.2 \pm 3.4$ \\
Red cell lysate & $20.0 \pm 2.7$ & $8.3 \pm 1.1$ \\
DNA & $1.5 \pm 0.2$ & $0.6 \pm 0.1$ \\
\hline
\end{tabular}

Values are means $\pm \mathrm{SD}, \mathrm{N}=3$.

aliquot of each fraction was counted in $7 \mathrm{~mL}$ Scintiverse BD (Fisher Scientific, Fair Lawn, NJ) on a Beckman LS 7000 Scintillation Counter.

Extraction of heme and heme adducts. $\left[{ }^{14} \mathrm{C}\right]-$ Artemisinin-labeled erythrocyte lysate and catalase were both prepared as described above. The heme and protein moieties were separated by a modification of the method of Fuhrhop and Smith [18]. Aliquots of $500 \mu \mathrm{L}$ were mixed with $10 \mathrm{~mL}$ ethyl acetate, followed by $500 \mu \mathrm{L}$ of glacial acetic acid/saturated $\mathrm{Na}_{2} \mathrm{SO}_{4}(4: 1)$ in a glass tube. The tubes were inverted, an equal volume of $1 \% \mathrm{Na}_{2} \mathrm{SO}_{4}$ was added, and the mixtures were shaken briefly by hand. The tubes were allowed to sit until the mixtures separated into two layers. The organic layer contained more than $99 \%$ of the total heme, and no detectable heme was left in the aqueous phase as determined by the pyridine hemochromogen assay [18]. Both layers were recovered and counted separately as described above.

Buffer and $p H$ effects on binding of artemisinin and derivatives to albumin. HSA (1 mg) was dissolved in $1 \mathrm{~mL}$ of each of the following buffers: PBS (pH 7.4); PBS (pH 8.6); Tris (150 mM, pH 7.4); and Tris (150 mM, pH 8.6). Unlabeled artemisinin, dihydroartemisinin, or deoxyartemisinin was added to a final concentration of $1 \mathrm{mM}$ from a $10 \mathrm{mM}$ ethanolic stock solution. Controls lacking protein were prepared simultaneously. Mixtures were incubated at $37^{\circ}$ for $24 \mathrm{hr}$. Proteins were separated from free drug by four spins through Centricon-30 microconcentrators (Amicon Division, W.R. Grace \& Co., Beverly, MA). Concentrates were recovered and diluted to a protein concentration of $1 \mathrm{mg} / \mathrm{mL}$. Spectra were obtained on a Hewlett Packard model 8452 Spectrophotometer.

\section{RESULTS}

$\left[{ }^{14} \mathrm{C}\right]$ Artemisinin bound covalently to various proteins (Table 1). Up to $18 \%$ of the total label eluted in the high molecular weight fraction that contained $>99 \%$ of the total protein. In the absence of protein, $<1 \%$ of the added radioactivity eluted in this fraction.

All of the hemoproteins tested bound artemisinin. Catalase and cytochrome $c$ bound 8 and 5\%, respectively, of added drug. Methemoglobin bound the most drug, $18 \%$ of the total. Fresh blood lysates,
Table 2. Percentage of protein-associated $\left[{ }^{14} \mathrm{Clartemisinin}\right.$ recovered by hemin extraction

\begin{tabular}{lc}
\hline \multicolumn{1}{c}{ Protein } & Percent extracted \\
\hline Hemoglobin & $20.0 \pm 0.6$ \\
Catalase & $18.3 \pm 0.3$ \\
Albumin & $8.5 \pm 0.1$ \\
\hline
\end{tabular}

Values are means $\pm S D, N=3$.

which consist predominantly of reduced hemoglobin, bound only $8 \%$ of total radioactivity. In contrast, heme-free globin bound negligible amounts of drug $(1.6 \%)$.

HSA only bound a very small percentage $(2.4 \%)$ of radioactive artemisinin. However, fatty acid-free HSA bound substantially more drug (11\%), suggesting that artemisinin can bind and react in the hydrophobic pocket of the protein. There was no binding to DNA (less than 1\%).

To determine whether the hemoprotein-bound $\left[{ }^{14} \mathrm{C}\right]$ artemisinin is associated with protein or heme, the protein and heme moieties were separated by extraction (Table 2). For both hemoglobin and catalase, only approximately $20 \%$ of the proteinassociated radioactivity was recovered in the ethyl acetate layer, which contained $>99 \%$ of the original heme content. When artemisinin-labeled HSA (which does not contain heme) was used as a control for this extraction, $8 \%$ of total radioactivity was detected in the ethyl acetate layer. These data suggest that when hemoglobin and catalase are alkylated, most of the drug becomes attached to the protein moiety,

The reaction between artemisinin and HSA was $\mathrm{pH}$ and buffer dependent (Fig. 1). Artemisininbound HSA had a distinct absorption peak at $306 \mathrm{~nm}$. The area of the peak reflected the relative amount of alkylated protein, since it increased with reaction time (data not shown). Reactions at $\mathrm{pH} 7.4$ in either PBS or Tris buffer were less efficient than in the corresponding $\mathrm{pH} 8.6$ buffer. The reaction of artemisinin with HSA, therefore, is favored at high pH. Reactions in PBS at both pH 7.4 and 8.6 were more efficient than in Tris at the same $\mathrm{pH}$ levels.

To better understand the binding of artemisinin 


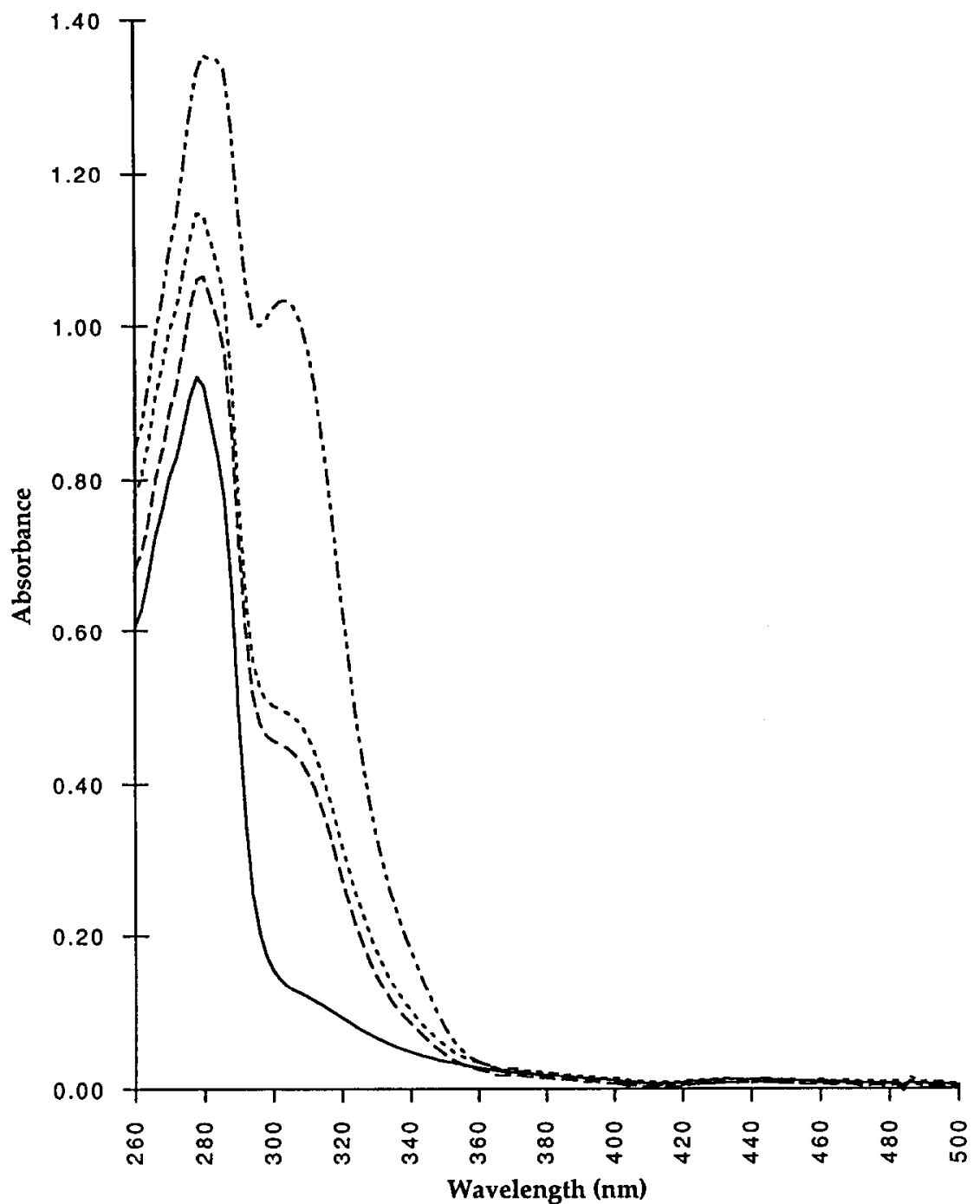

Fig. 1. Effects of $\mathrm{pH}$ and buffer on the absorption spectra of artemisinin-HSA adducts. HSA was incubated with $1 \mathrm{mM}$ artemisinin for $24 \mathrm{hr}$ and then separated from frec drug as described in Materials and Methods. Incubations were performed in PBS, pH $7.4(--)$; $\mathrm{PBS}, \mathrm{pH} 8.6(---)$; Tris, $\mathrm{pH} 7.4$ $(-)$; and Tris, $\mathrm{pH} 8.6(\cdots-\cdots)$.

to HSA, two derivatives of artemisinin, dihydroartemisinin and deoxyartemisinin, were also used to study binding (Fig. 2). Artemisinin appeared to be more reactive than either derivative. However, there was a definite reaction between HSA and dihydroartemisinin, an active artemisinin derivative. The endoperoxide bridge appears to be necessary for the reaction since deoxyartemisinin, an inactive derivative, did not react with HSA.

\section{DISCUSSION}

Artemisinin has been shown previously to form covalent adducts with HSA [12], red cell membrane proteins [13], and heme [14,15]. Heme and iron catalyse the decomposition of artemisinin into reactive free radicals [10] and electrophiles [11], which could act as alkylating agents. This could explain the selective toxicity of artemisinin derivatives to malaria, since malaria parasites have high intracellular stores of heme. These reactions could also explain some of the adverse effects of the drug [19]. However, both iron-dependent and independent reactions between artemisinin and HSA have been observed [12]. Thus, further work was needed to define the role of heme and iron as catalysts for protein alkylation.

In the present study, hemoproteins, such as hemoglobin, catalase, and cytochrome $c$, were found to react quite well with artemisinin. Most of the hemoglobin- or catalase-bound radioactivity was associated with the protein moiety rather than the heme. Yet heme-free globin did not react with artemisinin. These data suggest that in hemoproteins heme catalyses the alkylation of the protein moiety. 


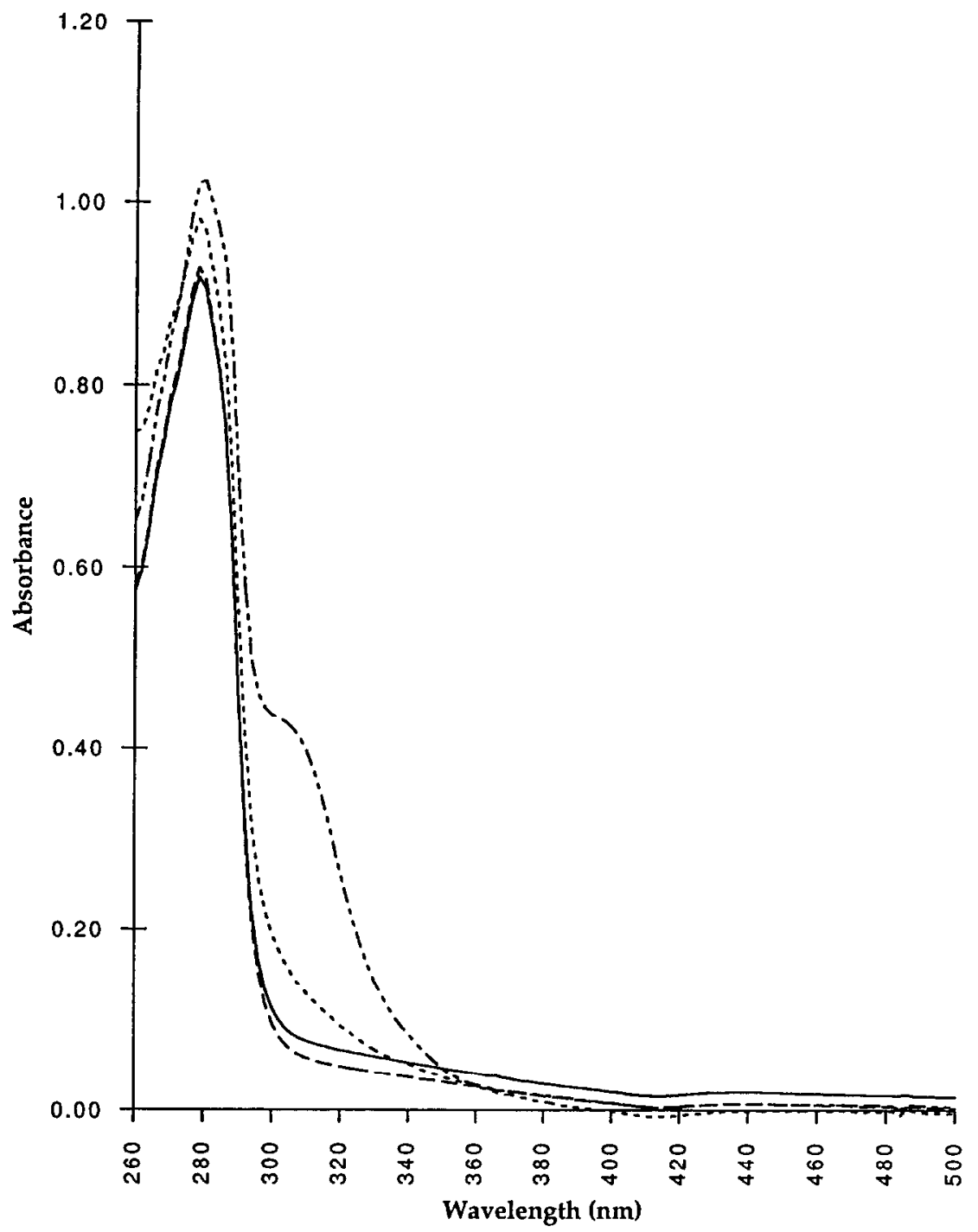

Fig. 2. Absorption spectra of HSA after reaction with artemisinin (-..-), dihydroartemisinin (-.....), deoxyartemisinin $(--)$, and in the absence of drug (-). HSA was incubated with $1 \mathrm{mM}$ concentrations of the drugs for $24 \mathrm{hr}$ in Tris buffer ( $\mathrm{pH} \mathrm{8.6)}$ and then separated from free drug as described in Materials and Methods.

Many alkylating agents target DNA [20]. Thus, it was necessary to determine whether artemisinin might act in this manner. However, the lack of reactivity between artemisinin and DNA suggests that DNA alkylation is not an important part of the mode of action of the drug.

HSA binds noncovalently to many drugs and small molecules, including fatty acids $[21,22]$. The binding of one compound is often influenced by the binding of a second compound, either by direct competition or by an allosteric interaction [22]. For example, fatty acids have been shown to inhibit the binding of dansylsarcosine by direct competition [23] and of diazepam allosterically $[24,25]$. The fact that more HSA is alkylated by artemisinin when it is fatty acidfree suggests that the drug may be binding at the fatty acid binding site, or a site that is allosterically regulated by fatty acid binding.

The reaction between artemisinin and HSA occurred faster at higher $\mathrm{pH}$. There are two possible explanations for this. First, artemisinin may decompose spontaneously at alkaline $\mathrm{pH}$ into a diketone that might be reactive with amino acids [26]. A second explanation is that protein amino groups become unprotonated at higher $\mathrm{pH}$ levels and are, therefore, better nucleophiles. Nucleophilic amines may also explain why the reaction proceeds better in PBS than in Tris buffer at identical pH, because the amino group in Tris may compete for the reaction with artemisinin.

Dihydroartemisinin is an important analog of artemisinin. It is the principle active metabolite of 
the three most important artemisinin derivatives in clinical use-artemether, arteether, and artesunate [4]. We have demonstrated previously that both artemisinin and dihydroartemisinin form covalent adducts with HSA [12]. Here we show that artemisinin forms a chromophore with HSA at a faster rate than dihydroartemisinin. This suggests either that the presence of a lactone moiety increases the reaction efficiency or that the dihydroartemisininHSA chromophore has a different structure than the artemisinin-HSA chromophore. In contrast, no chromophore forms when deoxyartemisinin is incubated with HSA, suggesting that there is no reaction. This implies that the endoperoxide bridge, which is necessary for antimalarial activity, is necessary for protein alkylation.

Acknowledgements-This work was supported by grants from the NIH (AI 26848) and the World Bank/UNDP/ WHO Special Programme for Research and Training in Tropical Diseases. We thank Dr. A. J. Lin for supplying us with deoxyartemisinin.

\section{REFERENCES}

1. Qinghaosu Antimalaria Coordinating Research Group, Antimalaria studies on qinghaosu. Chin Med J (Engl) 92: 811-816, 1979.

2. China Cooperative Research Group on Qinghaosu and its derivatives as Antimalarials, Chemical studies on qinghaosu artemisinin. J Tradit Chin Med 2: 3-8, 1982.

3. Klayman DI, Qinghaosu (artemisinin): An antimalarial drug from China. Science 228: 1049-1055, 1985.

4. Hien TT and White NJ, Qinghaosu. Lancet 341: 603608, 1993.

5. UNDP/World Bank/WHO Special Programme for Research and Training in Tropic Diseases, Tropical Disease Research Progress 1991-1992. World Health Organization, Geneva, 1993.

6. Krungkrai SR and Yuthavong Y, The antimalarial action of qinghaosu and artesunate in combination with agents that modulate oxidant stress. Trans $R$ Soc Trop Med Hyg 81: 710-714, 1987.

7. Meshnick SR, Tsang TW, Lin FB, Chang HZ, Kuypers F, Chiu D and Lubin B, Activated oxygen mediates the antimalarial activity of qinghaosu. Prog Clin Biol Res 313: 95-105, 1989.

8. Levander OA, Ager AL Jr, Morris VC and May RG, Qinghaosu, dietary vitamin E, selenium, and cod-liver oil: Effect on the susceptibility of mice to the malarial parasite Plasmodium yoelii. Am J Clin Nutr 50: 346352, 1989.

9. Meshnick SR, Yang YZ, Lima V, Kuypers F, Kamchonwongpaisan $S$ and Yuthavong $Y$, Irondependent free radical generation and the antimalarial artemisinin (qinghaosu). Antimicrob Agents Chemother 37: 1108-1114, 1993.

10. Zhang F, Gosser DK Jr and Meshnick SR, Hemincatalyzed decomposition of artemisinin (qinghaosu). Biochem Pharmacol 43: 1805-1809, 1992.

11. Posner $\mathrm{GH}$ and $\mathrm{Oh} \mathrm{CH}, \mathrm{A}$ regiospecifically oxygen-18 labeled 1,2,4-trioxane: A simple chemical model system to probe the mechanism(s) for the antimalarial activity of artemisinin (qinghaosu). $J$ Am Chem Soc 114: 83288329, 1992.

12. Yang Y-Z, Asawamahasakda $W$ and Meshnick SR, Alkylation of human albumin by the antimalarial artemisinin. Biochem Pharmacol 46: 336-339, 1993.

13. Asawamahasakda W, Benakis A and Meshnick SR, The interaction of artemisinin with red cell membranes. $J$ Lab Clin Med 123: 757-762, 1994.

14. Meshnick SR, Ranz A, Thomas A, Xu C-M and Pan $\mathrm{H}-\mathrm{Z}$, Artemisinin (qinghaosu): The role of intracellular hemin in its mechanism of antimalarial action. $\mathrm{Mol}$ Biochem Parasitol 49: 181-190, 1991.

15. Hong $Y-L$, Yang $Y-Z$ and Meshnick SR, The interaction of artemisinin with malarial hemozoin. Mol Biochem Parasitol 63: 121-128, 1994.

16. Dodge JT, Mitchell C and Hanahan DJ, The preparation and chemical characteristics of hemoglobin-free ghosts of human erythrocytes. Arch Biochem Biophys 100: 119-130, 1963

17. Bradford $M$, A rapid and sensitive method for the quantitation of microgram quantities of protein utilizing the principle of protein-dye binding. Anal Biochem 72: 248-254, 1976.

18. Fuhrhop JH and Smith KM, Laboratory methods. In: Porphyrins and Metalloporphyrins (Ed. Smith KM), pp. 757-869. Elsevier, Amsterdam, 1975.

19. Brewer TG, Grate SJ, Peggins JO, Weina PJ, Petras JM, Levin BS, Heiffer MH and Schuster BG, Fatal neurotoxicity due to arteether and artemether. $A m J$ Trop Med Hyg 47: 93, 1992.

20. Albert A, Selective Toxicity, 7th Edn. Chapman \& Hall, London, 1985.

21. Peters T Jr, Serum albumin. Adv Protein Chem 37: 161-245, 1985.

22. Fehske KJ, Müller WE and Wollert U, The location of drug binding sites in human scrum albumin. Biochem Pharmacol 30: 687-692, 1981.

23. Birkett DJ, Myers SP and Sudlow G, Effects of fatty acids on two specific drug binding sites on human serum albumin. Mol Pharmacol 13: 987-992, 1977.

24. Wong GB and Sellers EM, Intravascular factors affecting diazepam binding to human serum albumin. Biochem Pharmacol 28: 3265-3270, 1979.

25. Sjödin $T$, Circular dichroism studies on the inhibiting effect of oleic acid on the binding of diazepam to human serum albumin. Biochem Pharmacol 26: 2157$2161,1977$.

26. Zhao $S$ and Zeng MY, Application of precolumn reaction to high-performance liquid chromatography of qinghaosu in animal plasma. Anal Chem 58: 289 $292,1986$. 